\title{
Environmental Change and Zoonotic Disease Risk at Human-Macaque Interfaces in Bangladesh
}

\author{
Shahanaj Shano, ${ }^{1,2}$ Ariful Islam, ${ }^{2}$ Emily Hagan, ${ }^{2}$ Melinda K. Rostal, ${ }^{2}$ Stephanie Martinez, ${ }^{2}$ \\ Abdullah Al Shakil, ${ }^{1,2}$ Moushumi Hasan, ${ }^{1,2}$ Leilani Francisco, ${ }^{2,3}$ Mushtuq M. Husain, ${ }^{1}$ \\ Mahmudur Rahman, ${ }^{1}$ Meerjady S. Flora, ${ }^{1}$ Maureen Miller, ${ }^{2,4}$ Peter Daszak, ${ }^{2}$ \\ and Jonathan H. Epstein ${ }^{2}$ \\ ${ }^{1}$ Institute of Epidemiology, Disease Control and Research (IEDCR), Mohakhali, Dhaka-1212, Dhaka, Bangladesh \\ ${ }^{2}$ EcoHealth Alliance, New York, NY 10001, USA \\ ${ }^{3}$ Henry M. Jackson Foundation, Bethesda, MD 20817, USA \\ ${ }^{4}$ Mailman School of Public Health, Columbia University, New York, NY 10032, USA
}

\begin{abstract}
Anthropogenic land-use changes increase the frequency of interactions and habitat overlap between humans and macaques which play an important role in zoonotic disease transmission. This exploratory qualitative study aimed to examine connections between land-use change and macaque-human interactions and assess the chance of zoonotic disease transmission. We conducted ethnographic interviews and focus group discussions in Old Dhaka, Madaripur, and Chandpur, Bangladesh. Participants reported significant anthropogenic landscape transformations leading to increased human-macaque contact in the study areas. Participants also reported that all three sites underwent substantial landscape alteration from natural or agricultural land to a human-altered environment with roads, commercial, and residential buildings. Participants noted that the disappearance of forestland appeared to increase the macaque dependence on backyard fruit trees. Where rivers and ponds were filled to support local construction, macaques were also observed as becoming more dependent upon human water sources. These changed may help expanding the macaques' foraging areas, and they appear to be invading new areas where people are not culturally habituated to living with them. In response, many residents reported reacting aggressively toward the macaques, which they believed led to more bites and scratches. However, other respondents accepted the presence of macaques around their homes. Few participants considered macaques to be a source of disease transmission. This study revealed that local environmental changes, deforestation, urban expansion, construction, and water bodies' disappearance are linked to increasing human-macaque interactions. Understanding these interactions is critical to develop successful mitigation interventions at interfaces with a high risk for viral disease spillover.
\end{abstract}

Keywords: Rhesus macaque, Human-wildlife interface, Anthropogenic changes, Qualitative

\section{INTRODUCTION}

Shahanaj Shano and Ariful Islam these two authors equally contributed to this work.

Published online: November 8, 2021

Correspondence to: Ariful Islam, e-mail: arif@ecohealthalliance.org
Land-use change is a known driver of zoonotic disease transmission (Patz, 2004; Keesing, 2010; McFarlane, 2013). 
Anthropogenic landscape changes, including deforestation, construction of new buildings and roads, agricultural land encroachment, wetland modification, and urban area expansion, have increased rapidly with population growth (Keesing, 2010; Murray, 2013). Additionally, anthropogenic changes associated with the rate of human population growth often result in wildlife habitat reduction (Chomel, 2007). These changes are believed to increase human-wildlife interactions and drive and accelerate zoonotic disease emergence (Keesing, 2010; Murray, 2013; Gottdenker, 2014). The correlation between land-use change and disease emergence has previously been suggested, particularly in populous and tropical countries (Daszak, 2001; Jones, 2008; Allen, 2017). However, the types of land-use change and pathogen transmission mechanisms can vary significantly (Gottdenker, 2014). In many cases, urbanization and development can reduce some pathogens incidence while increasing others (Neiderud, 2015). Moreover, Rhesus macaques (Macaca mulatta) have experienced significant disturbance to their habitat in Bangladesh (Hasan, 2013).

Emerging Infectious Diseases (EIDs) like SARS-CoV-2, Ebola, SARS, MERS, Zika, and avian influenza viruses continue to be a significant global public health concern (Johnson, 2015; Ohimain, 2017). According to the World Health Organization (WHO), at least 30 new diseases have emerged over the last twenty years. Approximately $60 \%$ of EIDs are zoonotic (Jones, 2008) and are apparently driven by socio-economic, environmental, and ecological factors (McMichael, 2004; Nii-Trebi, 2017). Among these zoonoses, approximately $72 \%$ are caused by pathogens of wildlife origin (Jones, 2008). Non-human primates (NHPs) can harbor diverse zoonotic viruses (Karlsson, Small et al. 2015). NHPs can transmit several known pathogens, including rotavirus, tuberculosis, Yersinia pestis (plague), Leptospira sp., cercopithecine herpesvirus 1 (herpes B) (Jones-Engel, 2005; Fuentes, 2008). We have identified zoonotic viruses i.e.; rotavirus, adenovirus, and herpesvirus in rhesus macaques (Macaca mulatta) in Bangladesh (Anthony, 2015; Islam, 2019).

Rhesus macaque is one of the most populous and wellstudied NHP species in the world. They have high population densities and are widely distributed throughout South and Southeast Asia (Hasan, 2013). Rhesus macaques are genetically $93.5 \%$ identical to humans and are highly adaptable with ecological elasticity (Xue, 2016; Gibbs, 2007). In Bangladesh, the increasing human population coupled with rapid urbanization and deforestation have accelerated the fragmentation of macaque habitats (Hasan, 2013). Land-use change in Bangladesh has been reported to increase the frequency of macaque-human contact (Feeroz, 2013). Macaque populations have developed synanthropic characteristics (Hasan, 2013), where they flourish in ecological niches with humans, which facilitate the cross-species transmission of infectious diseases (Engel, O'Hara et al. 2010, Oberste et al. 2013).

As macaques are potential source of disease transmission to humans, it is necessary to understand human behaviors related to their interactions, including possible routes of exposure and disease transmission (Feeroz, 2013; Lane-deGraaf, 2014). Using mathematical methods, several studies have been conducted to examine macaque distribution, human-macaque conflict, and interactions from a conservation perspective (Hasan and Feeroz 2010, Ahsan and Uddin 2014, Naher et al. 2016). Little is known about how these conflicts and interactions may transmit disease to humans from macaques or vice versa. This qualitative study aimed to analyze the perception that environmental changes increase human-macaque interactions, thereby increasing zoonotic disease risks from macaques in Bangladesh. To our knowledge, this is the first qualitative study exploring the link between environmental changes increasing human-macaque interactions in Bangladesh.

\section{Methods}

\section{Study Sites}

Using our previous research (Anthony, 2015), we identified three study sites with large macaque populations in Bangladesh: Old Dhaka (Gandaria), Madaripur (Charmuguria), and Chandpur (Puran Bazar) (Fig. 1). The sites also represented areas with varying levels of urbanization.

Old Dhaka (Gandaria), constructed during the British colonial period, is a densely populated and congested urban area that has little to no space between adjacent buildings for vegetation (Kabir and Parolin 2012; Rahman and Zhang 2018). Madaripur (Charmuguria) is a peri-urban area that has the largest macaque population among the three sites (Hasan, 2013). Chandpur (Puran Bazar) is a peri-urban area situated along the bank of the Meghna river in Southeast Bangladesh. Qualitative data were collected from these sites from August 2015 to January 2016. 


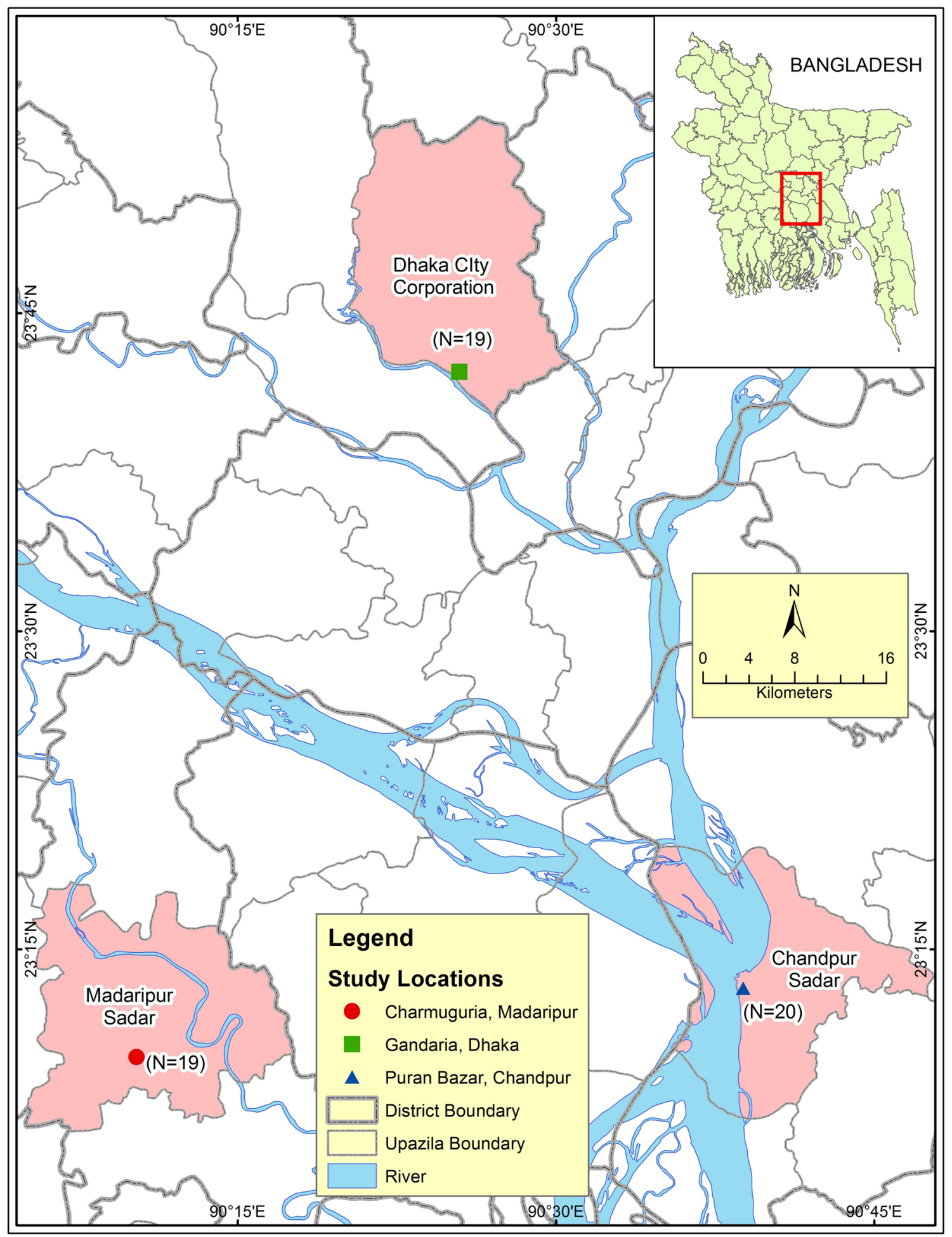

Fig. 1. Map of the study area. The sites where the qualitative work was done are given by town namedistrict name with the number of interviews from each site: Puran Bazar-Chandpur (blue triangle), Old Dhaka-Dhaka (green square), Charmuguria-Madaripur (red circle) (colour figure online).

\section{Ethical Considerations}

The Institutional Review Boards at the University of California, Davis $(754,490-03)$, and the Institute of Epidemi- ology, Disease Control and Research (IEDCR/IRB/2015/04) in Bangladesh approved the study protocol. As part of standard IRB-approved procedures, participants were in- 
formed about the purpose, procedures, risks, and benefits of participating in the study and could ask questions before providing informed and voluntary consent. After completing the interview, a modest token (handwashing kit) of appreciation was given to participants for their study participation. All participants identities were kept confidential, and unique identification numbers were assigned to each participants responses. For those under 18 years of age, assent was obtained from the participant, and informed consent was obtained from their parents or guardian.

\section{IDentifying Study Population}

Qualitative data were collected from community members in areas with synanthropic populations of macaques. At first, the study team asked residents about the macaques living history and their range in the study areas using the transect walk method. Then the team observed the type of human-macaque interactions and the contexts that could potentially facilitate disease spillover and transmission. During the observations, the team built a rapport with the community members and recruited study participants who had direct and indirect exposure to macaques.

\section{Data Collection}

Two trained qualitative interviewers conducted a total of $32 \mathrm{~h}$ of structured observations, fifty-eight ethnographic in-depth interviews (IDIs), and three focus group discussions (FGDs) at the three sites. Our team of anthropologists conducted observational research, IDIs (19 IDIs from Old Dhaka and Madaripur each, 20 IDIs from Chandpur), and one FGD at each location. The number of participants was determined based on the saturation level of qualitative research. Data saturation level was achieved when there were no new themes emerged after listening to the audio recordings, a careful reading of the transcripts, inductive and deductive codes (Saunders et al. 2018).

We used three observational methods to evaluate the nature of human-macaque contacts and any potential routes of disease transmission from macaques to humans at each site. These included field notes, checklists, and mapping. The team recorded notes about the observed environment and used checklists to note the occurrence and nature of human-macaque contacts. We used the social mapping technique to understand macaques' home ranges in the studied areas. The observational research was con- ducted during three sessions (early morning, mid-day, and late evening) each day. During the observations, the anthropologists' team built a rapport with community members and engaged in informal discussions to gain community people's trust in the team and find out eligible respondents (Narayanasamy 2009). All IDIs and FGDs were conducted in Bengali. The team used an interview guide with semi-structured questions and recorded all interviews with voice recorders. The semi-structured interview guides consisted of four core thematic areas: (1) human movement and the observed environment, (2) biosecurity and health, (3) human-macaque interactions, and (4) knowledge and perceptions of zoonosis to address risks for disease emergence (Saylors et al. 2021). Within those thematic areas, the researchers conducted the interviews focusing on the questions and asked necessary probing questions related to landscape and land-use change, the transformation of the macaques' natural habitat, and human-macaque conflict. The purpose of conducting FGDs was to further understand community perceptions of human-macaque interactions and rhesus macaques' conservation status. The people who had frequent direct interaction with macaques in the community and were willing to participate in our study were enrolled in the FGDs. To ensure diversity in the participants' category and achieve saturation level, we included people from both genders, different occupations, and age groups (Arcury and Quandt 1999). Each FGD began with a mapping activity that involved locating the local community and the macaque ranges in the area. This served as an icebreaker to build rapport, as a tool during the discussion, and as contextual data for analysis.

\section{Data Analysis}

A standardized codebook of key themes was developed for the larger global PREDICT-2 study that spanned 28 countries. This codebook was refined based on Bangladesh context. All IDIs and FGDs were conducted in Bengali, recorded, transcribed verbatim in Bengali, and then translated verbatim into English.

Observational field notes, IDIs and FGDs were imported into MAXQDA Analytical Pro, version 12 (VERBI Software, Berlin, Germany) for analysis. The qualitative data were analyzed iteratively, and the codebook was refined throughout the process to include the additional codes from emergent themes. 


\section{Results}

\section{Demographics}

We conducted 58 IDIs, among which 29 were female, 28 were male, and 1 was transgender participants. Our study participants were from different age groups and professions (Table 1). We enrolled 31 participants among all three FGDs, 12 were male, and 19 were female (Table 1).

\section{LAND-Use Change}

\section{Construction}

Fifty-six $(97 \% ; N=58)$ participants suggested that the environmental changes were associated with anthropogenic landscape conversion. At all three sites, both field observations and interviews described new buildings construction for residential purposes on agricultural land. Thirty-six $(62 \% ; N=58)$ participants from each site mentioned that "cutting of trees" or deforestation, and $44(76 \% ; N=58)$ participants stated that filling in natural water sources to build roads and apartment buildings was critical environmental problem (Table 2). They also noted that these changes destroy the natural habitat of macaques. For example, one participant from Chandpur said,

"There were too many trees that we do not have now. The number of trees is decreasing because of filling our land and wood demand. People made buildings and reformed their houses too. By filling the canal, people made their houses and increased the road size." (25year-old, female homemaker, Chandpur, 2016)

\section{Change to Environmental Resources}

Participants at all sites reported that wetland transformation and tree removal negatively impacted water availability. Several participants also stated that buildings were constructed over land created by filling in natural water

Table 1. Socio-demographic characteristics of the respondents participating in the in-depth interviews and focus group discussion by site.

\begin{tabular}{|c|c|c|c|c|c|c|}
\hline & \multicolumn{3}{|c|}{ In-depth interviews } & \multicolumn{3}{|c|}{ Focus group discussions } \\
\hline & DHK & $\mathrm{MD}$ & $\mathrm{CHD}$ & DHK & $\mathrm{MD}$ & $\mathrm{CHD}$ \\
\hline Number of participants & 19 & 19 & 20 & 15 & 9 & 7 \\
\hline \multicolumn{7}{|l|}{ Age (year) } \\
\hline$<18$ & - & 2 & 2 & 1 & - & 1 \\
\hline $18-30$ & 8 & 4 & 8 & 4 & - & 2 \\
\hline $31-40$ & 7 & 8 & 3 & 6 & 4 & 3 \\
\hline $41-50$ & - & - & 4 & 4 & 3 & - \\
\hline$>50$ & 4 & 5 & 3 & - & 2 & 1 \\
\hline \multicolumn{7}{|l|}{$\operatorname{Sex}$} \\
\hline Male & 10 & 9 & 9 & 8 & 4 & - \\
\hline Female & 9 & 10 & 10 & 7 & 5 & 7 \\
\hline Transgender & - & - & 1 & - & - & - \\
\hline \multicolumn{7}{|l|}{ Primary Occupation } \\
\hline Homemaker & 5 & 6 & 6 & 3 & - & 6 \\
\hline Business & 4 & 4 & 3 & 2 & - & - \\
\hline Cleaner & 1 & 1 & 1 & 8 & - & - \\
\hline Student & 1 & 1 & 4 & - & - & 1 \\
\hline Teacher & 3 & 1 & - & - & - & - \\
\hline Labor & - & 2 & 2 & 2 & 9 & - \\
\hline Service & 4 & 2 & - & - & - & - \\
\hline Rickshaw puller & - & 1 & 1 & - & - & - \\
\hline Other & 1 & 1 & 3 & - & - & - \\
\hline
\end{tabular}


Table 2. Reasons for environmental changes by site.

\begin{tabular}{llll}
\hline & DHK $(N=19) n(\%)$ & MD $(N=19) n(\%)$ & CHD $(N=20) \mathrm{n}(\%)$ \\
\hline Urban expansion and new construction & $19(100)$ & $17(89)$ & $14(70)$ \\
Filling in water bodies & $11(58)$ & $10(53)$ & $11(55)$ \\
"Cutting trees" (deforestation) & $12(63)$ & $16(84)$ & $8(40)$ \\
\hline
\end{tabular}

DHK Old Dhaka, MD Madaripur, CHD Chandpur

sources and explained that this led to a decline in human water transportation, as connecting waterways are now filled. Consequently, this lack of access to water transportation was associated with the development of roads, which eventually increased the demand for land. Furthermore, participants noted that erosion has severely affected the landscape. Many participants also suggested that the construction of residential buildings on former wetlands was one of the significant changes in their areas. Others stated that the increase in population size and river erosion had led people to build housing in alternative locations. To support this home construction, people needed to cut down trees and clear forest lands, which impacted macaque habitats. One of the participants mentioned:

"Because of increasing population density, more buildings are being built. And because of this, trees are decreasing in number. In order to build buildings, they cut down trees, clear out forest lands, then they build buildings there". (30-year-old, female homemaker, Chandpur, 2016)

\section{Connections Between Environmental Changes and Limited Access of Rhesus Macaque to Food and Water Sources}

According to study participants, as undeveloped land and natural water sources declined, macaques were perceived to be increasingly dependent on human structures, food, and water sources, which could create the potential for human food and water contamination and exacerbate humanmacaque conflict. We observed that macaques at all three sites mainly appeared dependent on the human provisioning of food and water. However, they also scavenge for foods and water in the natural sources in peri-urban areas. We also noted that at all locations, some people cultivated a commensal relationship with macaques. Many people reported that they regularly fed the macaques, whose population was thriving. Participants perceived that the size of the macaque troops grew within human settlements. Many participants said that the disappearance of natural forests likely led macaques to increasingly depend on fruit trees cultivated by households, which apparently increased contact with macaques.

One of the participants explained,

"There were a lot of trees, monkeys used to live on the trees. But now due to the scarcity of trees, as there is no shade to go under...So monkeys are going toward villages." (22-year-old, female, homemaker, Madaripur, 2015)

As natural water sources have been depleted, participants observed that macaques seemed more dependent on human water sources. For example, one participant from Gandaria, Dhaka, explained,

"If there is any tap outside, I mean water source.... They often come here and drink water opening the tap, and they leave it that way. .... We have a water tank on the rooftop. They came, broke the lid, and drunk water from the tank. So we could do nothing but throwing all the water and wash it." (27-year-old, female, service holder, Dhaka, 2015)

This dependence on human water sources can lead to water contamination, as an individual reported,

"Macaque comes on our roof, open the water tank, get their head into the tank and bathe in it, I've seen them doing it every day, so we lock the lid now. There are tanks on every building, they know it, and I have seen it, that's why I know." (27-year-old, female, homemaker, Dhaka, 2015)

\section{Dependence on Shared Food Sources Appears to Increase Macaque-Human Interactions}

Thirty-five $(60.34 \% ; N=58)$ participants reported that human-macaque conflict occurred in response to restricted 
food sources and lack of space. Some participants stated that food was the direct cause of conflict when macaques tried to secure food from people directly or from their homes. Observations and interviews revealed a shortage of natural food sources for macaques. One of the participants confirmed the macaques' dependence on humans for food, stating,

"There are hundreds of monkeys but no food. So, the only way they have food is to snatch from people as much as they can. Fruit trees are not available like before. So, what they would eat?" (50-year-old, male, farmer, Madaripur, 2015)

Participants repeatedly discussed the changing dietary patterns of macaques in their area. Many reported that monkeys depend either on stolen or snatched food or food provisioned by humans. Another participant said that,

"Suppose she is cooking in the kitchen and go inside the room to bring something. When she comes back from the room, she might find her rice pot missing. Macaque took food away". (40-year-old, male, school teacher, Madaripur, 2015)

One participant remarked that the lack of natural food resources had driven the monkeys to expand their foraging area, reporting,

"The monkeys have dispersed into different villages. Some monkeys have traveled up to forty miles looking for food." (35-year-old, male, businessman, Madaripur, 2015).

In interviews, some individuals mentioned macaques stealing food from households, streets, markets, or roads. Macaques were even reported to open refrigerators to remove food. Individuals expressed their frustration with macaques for their impudence. People believe macaques have developed skills to steal food as one of the participants commented,

"The monkeys even take away eggs by opening the fridge. They are very fond of eggs. Opening the fridge, keeping the eggs, they go away. Breaking the egg, they eat so nicely that it seems a man is eating. You can't imagine." (35-year-old, female, homemaker, Madaripur, 2015)

\section{Increased Human-Macaque Interactions and Food Scarcity Can Lead to More Antagonistic Interactions}

Thirty-eight $(65.52 \% ; N=58)$ participants reported that they or someone they knew had been bitten and 18 $(31.03 \% ; N=58)$ participants were scratched by a macaque on at least one occasion (Table 3). The participants in Madaripur District most frequently reported bites, scratches, and incidents where macaques chased people. In contrast, macaques snatching food from people were reported with nearly equal frequency at all three sites (Table 3). We also observed that macaque pulling on unattended clothes from home.

As one participant mentioned,

"Yes, macaques attacked us several times, and they bite people regularly." (35-year-old, female, day laborer, Madaripur, 2015)

One participant from Madaripur also reported that he was chased and scratched by macaques because he had cake in his hand. He stated,

"A monkey once chased me, and wanted to take a piece of cake from me. The monkey chased me because I had food on my hand and I got scratch and bleed." (27-year-old, male, a rickshaw puller, Madaripur, 2015)

\section{Knowledge, Perceptions, and Health-Seeking Behaviors}

Several participants reported that community members occasionally ate food that had been partially eaten by macaques, as they do not believe it is harmful. In the community, some people believe that leftover food of a macaque can cure respiratory diseases. One participant mentioned,

"In my childhood, I suffered from a severe cough. Someone said that monkey's leftover recovers respiratory problems. My grandfather gave puffed rice to the monkeys and brought the uneaten puffed rice for me after monkey's eating. I ate remaining puffed rice and recovered." (40-year-old, female, homemaker, Dhaka, 2016)

However, several participants mentioned that some people went to the doctor for bites and scratches and took the prescribed medications. One participant mentioned, 
Table 3. Types of direct contact between people and macaques as reported by participants by the site.

\begin{tabular}{llll}
\hline Potential contact & DHK $(N=19) n(\%)$ & MD $(N=19) n(\%)$ & CHD $(N=20) n(\%)$ \\
\hline Bites & $11(58)$ & $17(89)$ & $10(50)$ \\
Scratches & $8(42)$ & $7(37)$ & $3(15)$ \\
Chasing & $0(0)$ & $10(53)$ & $5(25)$ \\
Snatching food & $15(79)$ & $15(79)$ & $14(70)$ \\
\hline
\end{tabular}

DHK Old Dhaka, MD Madaripur, CHD Chandpur.

"Now usually people go to doctors. They take medicines and injections. Previously, people were not used to go to the doctor if the situation was not that much critical. They used to apply lime water on the wound. "(35-year-old, male, businessman, Madaripur, 2015)

Some local doctors also recommended a rabies vaccine as a preventative measure after a macaque bite. Another participant mentioned,

"Monkey's bite infects very much. It infects so much that the sore does not recover easily. Then we bought vaccine for vaccinating her five times. Then we did not get the free vaccine provided by the government. We got mental satisfaction after vaccination. Nevertheless, my daughter had much sufferings." (35-year-old, female, housewife, Madaripur, 2015)

Conversely, other participants stated that people sought traditional care when they were bitten or scratched by a macaque. One participant said that,

"Many Ayurveda doctors used to apply lime on the wound. Some used to apply sugar water. The wound used to dry up. After that, the sickness would go away". (35-year-old, male, businessman, Madaripur, 2015)

Another participant mentioned,

"I once got scratched, quite a while ago. There used to be a lot of monkeys in the school, there still are. I was given Pani Pora (sacred water), my mother asked for it". (36-year-old, female, housewife, Dhaka, 2016)

Some respondents reported fearing monkeys, and some said that a monkey bite or scratch would prompt them to seek professional medical attention. However, most had grown accustomed to interactions, including aggression from, and even attacks by, macaques living in their communities.

\section{Effective Mitigation Strategies to Facilitate Cohabi- tation}

Thirty-four $(58.62 \% ; N=58)$ participants indicated that regular human-macaque conflict frequently occurs to obtain food and habitation. Hence, participants suggested that the Bangladesh Government should regularly provide food for macaques. One Participant mentioned that,

"Between 2006 and 2009, food was provided to the monkey by the government. They offered food two times a day. That time monkey's disturbance was lesser in our locality. They provided banana, peanut, cucumber, etc. Now the macaques don't get food and enter the village for food. (60-year-old, male, businessman, Madaripur, 2015)

A few participants from Madaripur stated that they heard about an ecological park is being constructed on the opposite side of the river. After construction, they thought that all the macaques will be translocated there.

One participant mentioned that,

"The government will construct a park on the bank of the river. We heard that all monkeys would be shifted there. They have built a boundary like a park, and monkeys will be kept there. Monkeys will roam there and can't go out". (40-year-old, male, service holder, Madaripur, 2015)

Thirty-three $(56.89 \% ; N=58)$ participants reported that people are concerned about macaque's disturbance in their community. Community members have been reported to change their plans to plant orchards in order to prevent macaques from coming to their houses. Now community people like to plant non-fruiting trees rather than fruit trees in their backyard in the hopes that macaques will stay away from the household that does not have fruit trees. 


\section{Discussion}

This qualitative study described human-macaque interactions that could increase zoonotic disease emergence in three different communities of Bangladesh and revealed three pathways through which anthropogenic environmental change can increase human-macaque contact (Fig. 2). At all three regions, deforestation, conversion of water bodies into agricultural land or residential areas or road construction and urban expansion and development are all believed to contribute to human-macaque interactions by increasing macaque synanthropic and driving food and water scarcity in the natural environment. These pathways are enabled further by sociocultural factors, such as the historical, institutional provisioning of food to macaques.

The participants reported that changes to the natural and built environment are likely to increase contact rates between humans and macaques. Rapid human population growth in Bangladesh has been catalyzed by accelerated deforestation, construction, and infrastructure development (Islam, 2012). These ongoing expansions are more likely to increase the rates of contact between wildlife and people, change ecological responses, and force many wildlife populations out of their natural habitats (Khatun, 2012). Consequently, the large populations of NHPs and people in Bangladesh are perceived to be competing for shared resources (Feeroz, 2013). If the participant's observations are correct, this behavior likely increases the risk of zoonotic disease transmission from macaques to people. Anthropogenic and natural environmental changes, human population growth, and human behavior altogether impact human-wildlife interactions, which trigger the spillover and spread of pathogens (Daszak, 2000; Daszak, 2001). More than half of the older respondents (aged 50 years or more; $n=10$ out of 15) stated that the distribution of macaque and human populations overlap more than they did in the past, which could increase both the rate of contact between people and macaques and the risk of cross-species disease spillover. Our study suggests that the participants and the macaques at these three sites were frequently in close contact. This brings people into contact with a large pool of known and unknown zoonotic pathogens (Murphy, 1998; Mahy, 2000). Therefore, the risk of emerging and reemerging diseases between humans and macaques is likely increased in synanthropic regions, where both macaques and humans share similar ecology. Increased human population and their encroachment activities within macaques' natural habitat that increase the frequency of indirect interactions between macaques and humans (Hambali, 2012). Deforestation, construction, and urban expansion have previously been linked to increasingly overlapping distributions of macaque and human populations (Riley, 2007; Fuentes, 2008). Humans are at risk of infection with several different viruses carried by macaques, including simian foamy virus, simian retrovirus, cercopithecine herpesvirus 1 (herpes B virus) (Jones-Engel, 2005). Simian foamy virus transmission has already been documented in Bangladesh (Engel, 2013; Craig, 2015). Similarly, macaques can be infected by human diseases such as measles, rotavirus, and influenza (Fuentes, 2006). Previous studies have shown that humans and macaques frequent interaction at high-risk interfaces may increase the risk of zoonotic pathogen transmission from humans to macaques and vice
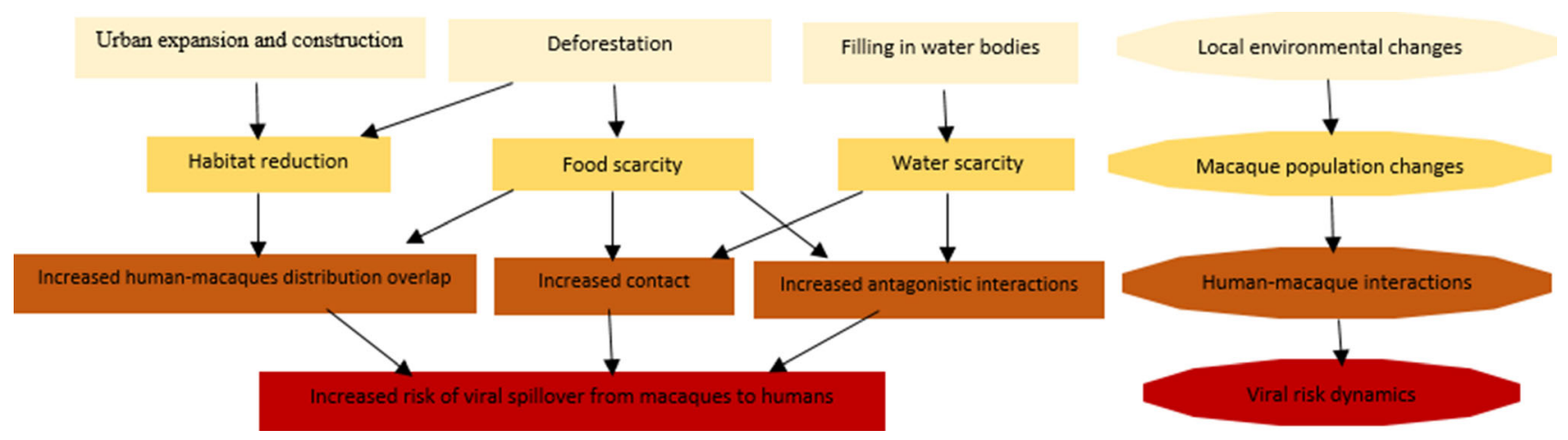

Fig. 2. A directed acyclic graph showing the relationships between anthropogenic environmental changes, changes in macaque populations and human-macaque interactions, and viral risk. This graph incorporates environmental change and the potential for increased risk of pathogen spillover from macaques to people. 
versa that poses health threats to macaques (Fuentes 2006, Islam et al. 2019).

The interviewees independently corroborated these reports on human-macaque interaction at all three study sites. The incidence of macaques taking food from children was more frequently reported in Madaripur (78.94\%; $N=19$ ). Other literature has reported macaques approaching, stealing from, and even attacking people, particularly when food is involved (Sha, 2009; Md-Zain, 2014). When macaques and people share the same water and food sources, pathogens can be transmitted indirectly through fomites. Macaques also access or seek access to peoples houses, wells, and wastewater storage sites. Sharing the same food sources was a key risk factor for simian foamy virus transmission to humans (Jones-Engel, 2005).

Community members removed fruits trees and planted non-fruiting trees in their yards to reduce contact with macaques, which, paradoxically, seemed to force macaques into homes to search for food and shelter; thus, increasing rather than decreasing rates of contact. People living in residential areas around the Kuala Selangor Nature Park reported a similar situation in Selangor District, Malaysia (Hambali, 2012). The results were like those identified in this study. In the absence of interventions to mitigate macaque habitat reduction/alteration, macaques will likely increasingly enter human spaces searching for food and water (Ahsan, 2014; Engel, 2013). The risk of zoonotic transmission of pathogens following frequent contact with macaques may be amplified due to behaviors and perceptions. Though $8(14 \% ; N=58)$ respondents had some understanding of germ theory and reported disposing of food touched by animals, $5(9 \% ; N=58)$ respondents believed that eating food contaminated by macaques had no negative impact and conveyed no risk. Seven (12\%; $N=58$ ) respondents also recognized a risk but continued to eat part of the contaminated food, reflecting the disconnection between risk-related knowledge and behavior in the presence of other pressures such as food shortage.

Macaques' ability to adapt to urban environments has likely increased the risk of macaque-human zoonotic disease transmission through their increased presence in these heavily populated areas. This is compounded by the fact that some in the study population were unaware of the zoonotic disease risks associated with interacting with macaques, such as eating food that was partially consumed or touching macaques or not seeking treatment after being bitten or scratched by a macaque. Urban expansion, construction, and development are necessary as economies grow and individuals and communities rise from poverty. However, suppose this development fails to compensate for the negative impact on the natural environment and wildlife behavior, frequent contact patterns between people and macaques can occur and introduce new zoonotic disease risks. These actions reduce natural sources of food, water, and shelter for macaques, driving them increasingly into urban areas and increasing contact with humans.

Moreover, food and water scarcity are perceived to have led to increasingly negative contact patterns between macaques and humans, as macaques attempt to obtain food and water resources directly from human dwellings or water storage sites.

\section{Limitations of the Study}

The study has several limitations. Due to the purposive sampling method, we conducted this study with a very specific population, particularly those who had direct and indirect contacts with macaques. Thus, the study was unable to capture other people's views Concerning this, we strongly recommend to undertake further studies using a population-based survey. In addition, the results of this study may not represent the situation of other areas of Bangladesh. Notably, we observed that macaques in all three sites appeared to depend on the human provisioning of food and water, which may not be similar in other areas of Bangladesh. However, as this is the first known qualitative study in Bangladesh that explored zoonotic disease risk by investigating anthropogenic changes and humanmacaque interaction, the findings of this study may use as the reference point for the future studies.

\section{Recommendations}

The study has a number of policy recommendations. Firstly, prioritizing the plantation of wild fruit trees as a source of natural food for macaques in macaque-dense areas of Bangladesh. This can reduce macaques' entry into human settlements. Secondly, with the support from Bangladesh Forest Department, and different non-government organization or society that are working on wildlife conservation should develop natural habitats for the rhesus macaques. Encouragement to develop a buffer zone or ecopark with large spaces and natural food sources could be a viable option as a permanent natural habitat for macaques. Finally, a multifaceted awareness raising intervention and conservation education programs with involving commu- 
nity people is highly recommended to reduce the anthropogenic changes and the pressure of habitat loss on the macaques and to increase community awareness about the future existence of the macaques in these areas. The intervention should also focus on improving peoples' understanding of disease transmission risks from wildlife. A rigorous process is required to follow for the successful design, implementation, and evaluation of these mitigation methods. Moreover, humans' positive attitude toward macaques might be the most effective option to strengthen all other approaches in cohabitation.

\section{ACKNOWLEDGEMENTS}

This study was supported by the American people through the United States Agency for International Development (USAID) Emerging Pandemic Threats PREDICT project (cooperative agreement number GHN-A-OO-09-0001000). We thank the Ministry of Health and Family Welfare, Bangladesh Forest Department and the Ministry of Environment and Forest for supporting this study. We thank Abdul Hai, Pitu Biswas, and Gafur Sheikh for their contributions to the study.

\section{REFERENCES}

Ahsan M, Uddin M (2014) Human-rhesus monkey conflict at rampur village under monohardi upazila in Narsingdi district of Bangladesh. Journal of Threatened Taxa 6(6):5905-5908. https:// doi.org/10.11609/JoTT.o3818.5905-8

Allen T, Murray KA, Zambrana-Torrelio C, Morse SS, Rondinini C, Di Marco M, Breit N, Olivial KJ, Daszak P (2017) Global hotspots and correlates of emerging zoonotic diseases. Nature Communication 8:1124. https://doi.org/10.1038/s41467-01700923-8

Anthony SJ, Islam A, Johnson C, Navarrete-Macias I, Liang E, Jain K, Hitchens PL, Che X, Soloyvov A, Hicks AL (2015) Nonrandom patterns in viral diversity. Nature Communications 6:17. https://doi.org/10.1038/ncomms9147

Arcury T, Quandt S (1999) Participant recruitment for qualitative research: A site-based approach to community research in complex societies. Human Organization 58(2):128-133. https:// doi.org/10.17730/humo.58.2.t5g838w7u1761868

Chomel BB, Belotto A, Meslin FX (2007) Wildlife exotic pets and emerging zoonoses. Emerging Infectious Diseases 13(1):6-11. https://doi.org/10.3201/eid1301.060480

Craig KL, Hasan MK, Jackson DL, Engel GA, Soliven K, Feeroz MM, Wang X, Jones-Engel L, Linial ML (2015) A seminomadic population in Bangladesh with extensive exposure to macaques does not exhibit high levels of zoonotic simian foamy virus infection. Journal of Virology 89:7414-7416. https://doi.org/ 10.1128/JVI.01065-15
Daszak P, Cunningham A, Hyatt A (2000) Emerging infectious diseases of wildlife-threats to biodiversity and human health. Science 287:443. https://doi.org/10.1126/science.287.5452.443

Daszak P, Cunningham A, Hyatt A (2001) Anthropogenic environmental change and the emergence of infectious diseases in wildlife. Acta Tropica 78:103-116. https://doi.org/10.1016/ S0001-706X(00)00179-0

Engel GA, O'Hara TM, Cardona-Marek T, Heidrich J, Chalise MK, Kyes R, Jones-Engel L (2010) Synanthropic primates in Asia: potential sentinels for environmental toxins. American journal of physical anthropology 142(3):453-460. https://doi.org/ 10.1002/ajpa.21247

Engel GA, Small CT, Soliven K, Feeroz MM, Wang X, Hasan MK, Oh G, Alam SR, Craig KL, Jackson DL (2013) Zoonotic simian foamy virus in Bangladesh reflects diverse patterns of transmission and co-infection. Emerging Microbes \& Infections 2:110. https://doi.org/10.1038/emi.2013.60

Feeroz MM, Soliven K, Small CT, Engel GA, Andreina Pacheco M, Yee JL, Wang X, Hasan MK, Oh G, Levine KL (2013) Population dynamics of rhesus macaques and associated foamy virus in Bangladesh. Emerging Microbes \& Infections 2:1-14. https:// doi.org/10.1038/emi.2013.23

Fuentes A (2006) Human culture and monkey behavior: assessing the contexts of potential pathogen transmission between macaques and humans. American Journal of Primatology 68:880896. https://doi.org/10.1002/ajp.20295

Fuentes A, Kalchik S, Gettler L, Kwiatt A, Konecki M, Jones-Engel L (2008) Characterizing human-macaque interactions in Singapore. American Journal of Primatology 70:879-883. https:// doi.org/10.1002/ajp.20575

Gibbs RA, Rogers J, Katze MG, Bumgarner R, Weinstock GM, Mardis ER, Remington KA, Strausberg RL, Venter JC, Wilson RK, Batzer MA, Bustamante CD, Eichler EE, Hahn MW, Hardison RC, Makova KD, Miller W, Milosavljevic A, Palermo RE, Siepel A, Sikela JM, Attaway T, Bell S, Bernard KE, Buhay CJ, Chandrabose MN, Dao M, Davis C, Delehaunty KD, Ding Y, Dinh HH, Dugan-Rocha S, Fulton LA, Gabisi RA, Garner TT, Godfrey J, Hawes AC, Hernandez J, Hines S, Holder M, Hume J, Jhangiani SN, Josi V, Khan ZM, Kirkness EF, Cree A, Fowler RG, Lee S, Lewis LR, Li Z, Liu YS, Moore SM, Muzny D, Nazareth LV, Ngo DN, Okwuonu GO, Pai G, Parker D, Paul HA, Pfannkoch C, Pohl CS, Rogers YH, Ruiz SJ, Sabo A, Santibanez J, Schneider BW, Smith SM, Sodergren E, Svatek AF, Utterback TR, Vattathil S, Warren W, White CS, Chinwalla AT, Feng Y, Halpern AL, Hillier LW, Huang X, Minx P, Nelson JO, Pepin $\mathrm{KH}$, Qin X, Sutton GG, Venter E, Walenz BP, Wallis JW, Worley KC, Yang SP, Jones SM, Marra MA, Rocchi M, Schein JE, Baertsch R, Clarke L, Csuros M, Glasscock J, Harris RA, Havlak P, Jackson AR, Jiang H, Liu Y, Messina DN, Shen Y, Song HX, Wylie T, Zhang L, Birney E, Han K, Konkel MK, Lee J, Smit AFA, Ullmer B, Wang H, Xing J, Burhans R, Cheng Z, Karro JE, Ma J, Raney B, She X, Cox MJ, Demuth JP, Dumas LJ, Han SG, Hopkins J, Karimpour-Fard A, Kim YH, Pollack JR, Vinar T, Addo-Quaye C, Degenhardt J, Denby A, Hubisz MJ, Indap A, Kosiol C, Lahn BT, Lawson HA, Marklein A, Nielsen R, Vallender EJ, Clark AG, Ferguson B, Hernandez RD, Hirani K, Kehrer-Sawatzki H, Kolb J, Patil S, Pu L, Ren Y, Smith DG, Wheeler DA, Schenck I, Ball EV, Chen R, Cooper DN, Giardine B, Hsu F, Kent WJ, Lesk A, Nelson DL, O’brien WE, Prufuer K, Stenson PD, Wallace JC, Ke H, Liu XM, Wang P, Xiang AP, Yang F, Barber GP, Haussler D, Karolchik D, Kern AD, Kuhn RM, Smith KE, Zwieg AS (2007) Evolutionary and biomedical insights from the rhesus macaque genome. Science 316:222-234. https://doi.org/10.1126/science.1139247 
Gottdenker NL, Streicker DG, Faust CL, Carroll C (2014) Anthropogenic land use change and infectious diseases: a review of the evidence. Ecohealth 11:619-632. https://doi.org/10.1007/ s10393-014-0941-Z

Hambali K, Ismail A, Zulkifli SZ, Md-Zain BM, Amir A (2012) Human-macaque conflict and pest behaviors of long-tailed macaques (Macaca fascicularis) in Kuala Selangor Nature Park. Tropical Natural History 12:189-205; https://li01.tci-thaijo.org/ index.php/tnh/article/view/103050

Hasan M, Feeroz M (2010) Distribution and status of long-tailed macaque (Macaca fascicularis aurea I. Geoffroy Saint-Hilaire 1830) in Bangladesh. Journal of Threatened Taxa 2(12):13421344

Hasan MK, Aziz MA, Alam SR, Kawamoto Y, Jones-Engel L, Kyes RC, Akhtar S, Begum S, Feeroz MM (2013) Distribution of Rhesus Macaques (Macaca mulatta) in Bangladesh: inter-population variation in group size and composition. Primate Conservation 26:125-132. https://doi.org/10.1896/052.026.0103

Islam K, Sato N (2012) Deforestation, land conversion and illegal logging in Bangladesh: The case of the Sal (Shorea robusta) forests. iForest-Biogeosciences and Forestry 5(3):171-178. https:// doi.org/10.3832/ifor0578-005

Islam A, Hossain ME, Haider N, Rostal MK, Mukharjee SK, Ferdous J, Miah M, Rahman M, Daszak P, Rahman MZ (2019) Molecular characterization of group a rotavirus from rhesus macaques (Macaca mulatta) at human-wildlife interfaces in Bangladesh. Transboundary and emerging diseases 67(2):956966. https://doi.org/10.1111/tbed.13431

Johnson CK, Hitchens PL, Evans TS, Goldstein T, Thomas K, Clements A, Joly DO, Wolfe ND, Daszak P, Karesh WB (2015) Spillover and pandemic properties of zoonotic viruses with high host plasticity. Scientific reports 5:14830. https://doi.org/10.1038/ srep 14830

Jones KE, Patel NG, Levy MA, Storeygard A, Balk D, Gittleman JL, Daszak P (2008) Global trends in emerging infectious diseases. Nature 451:990-993. https://doi.org/10.1038/nature06536

Jones-Engel L, Engel GA, Schillaci MA, Rompis A, Putra A, Suaryana KG, Fuentes A, Beer B, Hicks S, White R (2005) Primate-to-human retroviral transmission in Asia. Emerging infectious diseases 11:1028. https://doi.org/10.3201/ eid1107.040957

Kabir A, Parolin B (2012). Planning and development of Dhaka-a story of 400 years. 15th international planning history society conference.

Karlsson EA, Small CT, Freiden P, Feeroz MM, Matsen FA IV, San S, Hasan MK, Wang D, Jones-Engel L, Schultz-Cherry S (2015) Non-human primates harbor diverse mammalian and avian astroviruses including those associated with human infections. PLoS pathogens 11(11):e1005225

Keesing F, Belden LK, Daszak P, Dobson A, Harvell CD, Holt RD, Hudson P, Jolles A, Jones KE, Mitchell CE (2010) Impacts of biodiversity on the emergence and transmission of infectious diseases. Nature 468:647-652. https://doi.org/10.1038/nature09575

Khatun UH, Ahsan MF, Roslash E (2012) Attitudes of the local community towards the conservation of the common langur (Semnopithecus entellus) in Keshabpur, Bangladesh. International Journal of Biodiversity and Conservation 4:385-399. https://doi.org/10.5897/IJBC12.035

Lane-deGraaf KE, Putra IGAA, Wandia IN, Rompis A, Hollocher $\mathrm{H}$, Fuentes A (2014) Human behavior and opportunities for parasite transmission in communities surrounding long-tailed macaque populations in Bali, Indonesia. American Journal of Primatology 76:159-167. https://doi.org/10.1002/ajp.22218

Mahy B, Brown CC (2000) Emerging zoonoses: crossing the species barrier. Revue Scientifique et Technique International Office of Epizootics 19:33-40. https://doi.org/10.20506/ rst.19.1.1212

Mcfarlane RA, Sleigh AC, Mcmichael AJ (2013) Land-use change and emerging infectious disease on an island continent. International Journal of Environmental Research and Public Health 10:2699-2719. https://doi.org/10.3390/ijerph10072699

McMichael AJ (2004) Environmental and social influences on emerging infectious diseases: past, present and future. Philosophical Transactions of the Royal Society of London b: Biological Sciences 359:1049-1058. https://doi.org/10.1098/rstb.2004.1480

Md-Zain B, Ruslin F, Idris WMR (2014) Human-Macaque Conflict at the Main Campus of Universiti Kebangsaan Malaysia. Pertanika Journal of Tropical Agricultural Science 37(1):73-85

Murphy FA (1998) Emerging zoonoses. Emerging Infectious Diseases 4:429. https://doi.org/10.3201/eid0403.980324

Murray KA, Daszak P (2013) Human ecology in pathogenic landscapes: two hypotheses on how land use change drives viral emergence. Current Opinion in Virology 3:79-83. https:// doi.org/10.1016/j.coviro.2013.01.006

Naher H, Khan SI, Ahmed T (2016) Population status and distribution of Rhesus Macaque, Macaca mulatta, in a moist deciduous forest of Bangladesh. Bangladesh Journal of Zoology 44(1):60-72

Narayanasamy N (2009) Participatory Rural Appraisal: Principles, India: Methods and Application. SAGE Publications Ltd.

Neiderud CJ (2015) How urbanization affects the epidemiology of emerging infectious diseases. Infection ecology \& epidemiology 5:27060. https://doi.org/10.3402/iee.v5.27060

Nii-Trebi NI (2017) Emerging and neglected infectious diseases: insights, advances, and challenges. BioMed Research International . https://doi.org/10.1155/2017/5245021

Oberste MS, Feeroz MM, Maher K, Nix WA, Engel GA, Hasan KM, Begum S, Oh G, Chowdhury AH, Pallansch MA, JonesEngel L (2013) Characterizing the picornavirus landscape among synanthropic nonhuman primates in Bangladesh, 2007 to 2008. Journal of Virology 87(1):558-571. https://doi.org/ 10.1128/JVI.00837-12

Ohimain EI (2017) Emerging pathogens of global significance, priorities for attention and control. EC Microbiology 56:215-240

Patz JA, Daszak P, Tabor GM, Aguirre AA, Pearl M, Epstein J, Wolfe ND, Kilpatrick AM, Foufopoulos J, Molyneux D (2004) Unhealthy landscapes: policy recommendations on land use change and infectious disease emergence. Environmental health perspectives 112:1092. https://doi.org/10.1289/ehp.6877

Rahman K, Zhang D (2018) Analyzing the level of accessibility of public urban green spaces to different socially vulnerable groups of people. Sustainability 10(11):3917. https://doi.org/10.3390/ su 10113917

Riley EP (2007) The human-macaque interface: conservation implications of current and future overlap and conflict in Lore Lindu National Park, Sulawesi, Indonesia. American Anthropologist 109:473-484. https://doi.org/10.1525/aa.2007.109.3.473

Saunders B, Sim J, Kingstone T, Baker S, Waterfield J, Bartlam B, Burroughs H, Jinks C (2018) Saturation in qualitative research: exploring its conceptualization and operationalization. Quality \& Quantity 52(4):1893-1907. https://doi.org/10.1007/s11135017-0574-8 
Saylors K, Wolking DJ, Hagan E, Martinez S, Francisco L, Euren J, Olson SH, Miller M, Fine AE, Thanh NN, Minh PT (2021) Socializing One Health: an innovative strategy to investigate social and behavioral risks of emerging viral threats. One Health Outlook 3(1):1-6. https://doi.org/10.1186/s42522-021-00036-9

Sha JCM, Gumert MD, Lee BPH, Jones-Engel L, Chan S, Fuentes A (2009) Macaque-human interactions and the societal perceptions of macaques in Singapore. American Journal of Pri- matology: Official Journal of the American Society of Primatologists 71:825-839. https://doi.org/10.1002/ajp.20710

Xue C, Raveendran M, Harris RA, Fawcett GL, Liu X, White S, Dahdouli M, Deiros DR, Below JE, Salerno W (2016) The population genomics of rhesus macaques (Macaca mulatta) based on whole-genome sequences. Genome research 26:16511662. https://doi.org/10.1101/gr.204255.116 